\title{
Pengembangan E-Modul Ekonomi Mata Pelajaran Ekonomi Bisnis Materi Pelaku Ekonomi Untuk Siswa Kelas X AKL 1 SMKN 2 Kediri
}

\author{
Kusnul Khotimah', Elis Irmayanti ${ }^{2}$, Bayu Surindra ${ }^{3}$ \\ kusnul359@gmail.com ${ }^{1}$, elis@ unpkediri.ac.id ${ }^{2}$, bayusurindra@ unpkediri.ac.id $^{3}$ \\ Pendidikan Ekonomi \\ Fakultas Ekonomi dan Bisnis \\ Universitas Nusantara PGRI Kediri ${ }^{123}$
}

\begin{abstract}
Abstrak
Dalam penelitian memiliki tujuan untuk mengahasilkan e-Modul ekonomi untuk siswa kelas X AKL 1 SMKN 2 Kediri. Metode yang dipakai dalam pengembangan pada penelitian ini adalah dengan pengembangan model ADDIE melalui lima tahapan, namun pada penelitian saat ini dibatasi sampai empat tahap. Uji validasi kepada tiga validator ahli, yaitu validator ahli materi, validator ahli media, dan validator ahli bahasa. Uji validasi dalam penelitian ini dilaksanakan melalui dua tahap. Hasil uji validasi ahli materi pada tahap pertama mendapatkan nilai sebesar $80,83 \%$ dengan kriteria baik, mengalami peningkatan hasil pada tahap kedua dengan nilai 90,83\% dengan kriteria sangat baik. Pada uji validasi ahli media media tahap pertama mendapatkan nilai $75 \%$ dengan kriteria cukup, dan tahap kedua meningkat dengan nilai 93,75\% dengan kriteria sangat baik. Selanjutnya untuk uji validasi ahli bahasa mendapatkan nilai dengan kriteria cukup yaitu sebesar 65,63\% dan meningkat pada tahap kedua sebesar $87,5 \%$ dengan kriteria baik. e-Modul yang saat ini dikembangkan dirasa cukup efektif dalam menunjang pembelajaran di kelas. Siswa bisa mengakses pada gadget masing-masing, tidak terlalu banyak menghabiskan kuota internet, disusun secara sistematis, serta disusun berdasarkan pedoman pegembangan e-Modul oleh Direktorat Pembinaan SMA.
\end{abstract}

Kata kunci : e-modul, mata pelajaran ekonomi

\begin{abstract}
In research, it aims to result in e-Module economics for students of class X AKL 1 SMKN 2 Kediri. The method used in the development of this research is to develop the ADDIE model through five stages, but in the current research is limited to four stages. Validation test to three expert validators, namely material expert validator, media expert validator, and linguist validator. The validation test in this study was carried out through two stages. The results of the material expert validation test in the first stage received a score of $80.83 \%$ with good criteria, experiencing an increase in results in the second stage with a value of $90.83 \%$ with excellent criteria. In the validation test the first stage media media experts get a score of $75 \%$ with sufficient criteria, and the second stage increases with a value of $93.75 \%$ with excellent criteria. Furthermore, for the validation test linguists get a score with sufficient criteria of $65.63 \%$ and increase in the second stage by $87.5 \%$ with good criteria. e-Modules that are currently developed are considered quite effective in supporting classroom learning. Students can access on their respective gadgets, not spend too much internet quota, arranged systematically, and compiled based on eModule development guidelines by the Directorate of High School Development.
\end{abstract}

Keyword: e-module, economics subject 


\section{Jurnal PINUS: Jurnal Penelitian Inovasi Pembelajaran, 7 (1), 2021,}

Kusnul Khotimah, Elis Irmayanti, Bayu Surindra

\section{PENDAHULUAN}

Pendidikan merupakan suatu upaya memanusiakan manusia serta menyadarkan manusia akan tempatnya sebagai pemimpin di dunia, sehingga semakin mengasah dirinya untuk menjadi manusia yang beriman, bertaqwa, mengerti dan berbuat baik.

Hal tersebut didukung oleh Mudyahardjo (2012) pendidikan ialah seperangkat pengalaman dalam proses pembelajaran yang pelaksanaanya diharapkan dapat berlangsung sepanjang hayat. Pendidikan merupakan suatu keadaan mengenai kehidupan manusia terutama dalam mempengaruhi pertumbuhan manusia secara individu.

Pendidikan berarti instruksi atau dukungan yang sengaja diberikan orang dewasa untuk menjadikan seseorang lebih dewasa. Yang dimaksud dengan dewasa yaitu dapat seseorang yang mampu mempertanggungjawabkan segala sesuatunya terutama terhadap dirinya sendiri baik secara biologis, psikologis, pedagogis, dan sosiologis, Hasbullah (2012).

Sehubungan dengan adanya proses pembelajaran tersebut, mata pelajaran ekonomi yakni merupakan suatu bagian dari adanya suatu mata pelajaran yang dipelajari disekolah, mempelajari sikap pribadi dan berusaha untuk memuaskan kebutuhan serta keinginan mereka dalam hidup dengan sejumlah peralatan yang memuaskan. Banyak aspek yang mempengaruhi terhadap keberhasilan pelaksanaan pembelajaran ekonomi.
Faktor-faktor yang dimaksud seperti kemampuan pendidik secara mandiri untuk memahami atau mengakomodasi materi atau suatu permasalahan yang nantinya akan diajarkan kepada siswa, dan tersedianya fasilitas belajar. Salah satu sarana terpenting dalam mempelajari ilmu ekonomi adalah buku teks ekonomi. Kualitas buku teks ekonomi menjadi alat bantu dalam studi ekonomi sangat bergantung pada kemampuan peneliti untuk melengkapi e-modul tersebut. Hal tersebut memang ditujukan untuk mempermudah para pendidik ekonomi dan penulis buku teks mengorganisasikan literatur ekonomi.

Pandemi Covid-19 seperti pada saat ini sangat berdampak pada seluruh sektor, termasuk pada sektor pendidikan. Kegiatan pembelajaran yang sebelumnya dilaksanakan secara tatap muka di sekolah, kini tidak bisa dilakukan karena adanya pembatasan aktivitas sosial dalam rangka pencegahan penyebaran Covid-19. Pemerintah menetapkan untuk pembelajaran jarak jauh, sehingga siswa bisa mengikuti kegiatan pembelajaran dari rumah masing-masing.

Dengan keadaan seperti yang sudah dijelaskan di atas, maka seluruh sektor pendidikan harus kooperatif demi kelancaran kegiatan belajar mengajar. Mulai dari mendesain pembelajaran jarak jauh yang menarik sehingga siswa tidak bosan dan kegiatan pembelajaran berjalan dengan efektif. Siswa juga harus menyadari bahwa mereka membutuhkan ilmu yang salah satunya didapatkan dari 


\section{Jurnal PINUS: Jurnal Penelitian Inovasi Pembelajaran, 7 (1), 2021, Kusnul Khotimah, Elis Irmayanti, Bayu Surindra}

kegiatan pembelajaran untuk menjalankan kehidupan.

Pemanfaatan media pembelajaran di masa pandemi Covid-19 harus lebih selektif lagi, mengingat kegiatan pembelajaran yang dilaksanakan secara daring. Media pembelajaran sangatlah penting dalam kegiatan pembelajaran, dimana media pembelajaran akan menunjang kelancaran kegiatan belajar. Media pembelajaran merupakan berbagai macam bentuk media komunikasi yang bisa dimanfaatkan dalam memberikan informasi kepada siswa dari sumber belajar untuk memberikan stimulus berpartisipasi dalam pembelajaran, Uno (2014).

Dengan adanya media selain dapat dipakai dalam menyampiakan pembelajaran secara menyeluruh, media juga mampu dimanfaatkan untuk menyampaikan berbagai kegiatan pembelajaran pada tiap bagiannya, serta diharapkan mampu memberi suatu penguatan serta memberi motivasi kepada siswa.

Sumber belajar yang didalamnya tercantum media pendidikan ialah salah satu aspek yang mempengaruhi terhadap mutu implementasi kurikulum, spesialnya proses pendidikan. Proses pendidikan yang memaksimalkan sumber belajar membagikan pengalaman belajar yang kaya kepada anak didik, baik dalam wujud audio, visual, ataupun audio visual serta gerak. Dengan pendidikan yang variatif ini diharapkan bisa memotivasi anak didik buat belajar dengan aktif, kreatif, serta mengasyikkan sehingga hasil belajar bisa dicapai secara maksimal.

Sumber belajar sudah banyak ada, baik dalam jenis sumber belajar yang dirancang ataupun yang dimanfaatkan. Tugas pendidik merupakan gimana memilah, memilah, serta menggunakan bermacam sumber belajar yang sudah ada dalam mendukung proses pendidikan. Tetapi demikian, tidak terdapat larangan apalagi sangat disarankan seseorang pendidik buat menghasilkan sesuatu sumber belajar yang memanglah dirancang spesial buat kepentingan pendidikan.

Modul adalah seperangkat program yang ditata dalam bentuk unitunit tertentu serta dirancang secara seksama untuk kepentingan pembelajaran pada siswa, Ali (2007). Modul terdiri dari beberapa bagian lembar kegiatan siswa, lembar kerja siswa, lembar tes, kunci jawaban lembar tes, dan kunci jawaban latihan dan penilaian sesuai arahan guru.

Kemajuan teknologi yang sangat pesat mendorong sektor pendidikan untuk tetap mengikuti. Untuk menerapkan pembelajaran menggunakan media elektronik dibutuhkan media pembelajaran berupa e-Modul. Dimana eModul merupakan suatu media dalam bentuk elektronik yang penggunaannya dapat diakses dengan alat elektronik seperti laptop, komputer, bahkan melalui smartphone.

Pemanfaatan media pembelajaran secara baik dan tepat akan mampu membantu seorang guru dan siswa untuk 
Jurnal PINUS: Jurnal Penelitian Inovasi Pembelajaran, 7 (1), 2021, Kusnul Khotimah, Elis Irmayanti, Bayu Surindra

mencapai tujuan pembelajaran. Contoh media pembelajaran yang cocok untuk dipakai pada pembelajaran daring saat ini adalah dengan menggunakan e-Modul. Dari sisi biaya juga lebih efisien daripada penggunaan modul yang perlu dicetak dan digandakan agar dapat digunakan oleh siswa.

Berdasarkan hasil pengamatan di SMKN 2 Kediri dalam pembelajaran mata pelajaran ekonomi, diperoleh informasi bahwa di masa pandemi saat ini guru mengajar hanya dengan menggunakan materi pelajaran yang dikirimkan melalui WhatsApp Group kelas, hal tersebut dilakukan karena terdapat beberapa kendala seperti beberapa siswa yang bertempat tinggal pada suatu daerah yang memiliki jaringan internet tidak stabil sehingga tidak memungkinkan untuk melakukan video conference, sehingga alternatif yang dipilih adalah dengan mengirimkan materi pembelajaran di grup kelas yang cenderung membosankan dan kurang efektif dalam kegiatan pembelajaran.

Alasan peneliti memilih lokasi penelitian di SMKN 2 Kediri karena merupakan salah satu sekolah unggulan di Kota Kediri, memiliki berbagai prestasi baik prestasi individu maupun prestasi secara berkelompok. Serta yang menjadi alsan utama yaitu adanya suatu permasalahan terutama dalam proses pembelajaran yang dihadapi guru dan siswa yaitu mengenai media belajar yang masih kurang efektif penggunaannya dimasa pandemi saat ini karena kegiatan pembelajaran dilaksanakan secara online.

Salah satu bentuk media pembelajaran yang bisa dimanfaatkan guru pada materi yang diajarkan adalah dengan menggunakan e-Modul. Dengan eModul siswa bisa belajar mandiri, hal tersebut cocok untuk diterapkan di masa ini, karena guru yang tidak bisa mendampingi siswa dalam kegiatan pembelajaran secara langsung, selain itu mereka bisa belajar dengan tingkat pemahaman masing-masing, dan e-Modul bisa diakses pada gadget siswa masingmasing.

Berdasarkan latar bekang tersebut peneliti tertarik untuk melaksanakan suatu penelitian yang memiliki tujuan untuk menghasilkan adanya produk berupa eModul ekonomi pada mata pelajaran ekonomi bisnis materi pelaku ekonomi kelas X AKL 1 SMKN 2 Kediri.

\section{METODE}

Metode yang digunakan yaitu Research and Development (RnD), dimana RnD adalah suatu bentuk penelitian yang dipakai dalam menciptakan suatu produk dan dilakukan pengujian untuk mengetahui keefektifan produk tersebut (Sugiyono, 2017). Dari penjelasan tersebut bisa disimpulkan kalau Research and Development ini merupakan tata cara riset yang bertujuan buat menciptakan produk tertentu yang menunjang aktivitas pengajaran. Media pembelajaran pada penelitian ini berupa eModul pelajaran ekonomi untuk siswa 
Jurnal PINUS: Jurnal Penelitian Inovasi Pembelajaran, 7 (1), 2021, Kusnul Khotimah, Elis Irmayanti, Bayu Surindra

SMK kelas X. Penelitian dilaksanakan sesuai dengan Langkah-langkah model ADDIE. Model ADDIE ialah salah satu desain sistem pendidikan dengan tahapantahapan bawah sistem pendidikan yang simpel serta gampang buat dipelajari. Cocok dengan Namanya, model ini terdiri dari 5 fase ataupun tahapan, ialah: Analysis, Implement,

Design, Development, serta Evaluation, Pribadi (2011)

Model desain pembelajaran ADDIE ditunjukkan pada gambar berikut:

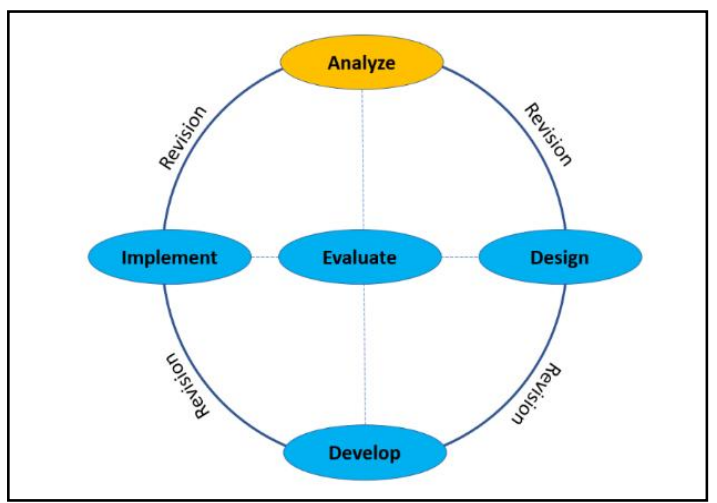

Gambar 1 Pengembangan Model ADDIE

Sumber: (Pribadi, 2011)

Subyek penelitian ini merupakan tim uji ahli atau validator ahli. Validator yang dimaksudkan dalam penelitian yakni akan memvalidasi media pembelajaran eModul yang dikembangkan dan dilaksanakan di SMK Negeri 2 Kediri yang berlokasi di Jl. Veteran No. 5 Kota Kediri.

Subyek uji coba penelitian ini yaitu tim uji ahli atau validator ahli. Validator yang dimaksudkan dalam penelitian yakni akan memvalidasi media pembelajaran e-Modul. Validasi merupakan kegiatan yang dilakukan guna mengetahui valid atau tidaknya media pembelajaran yang digunakan dengan menggunakan kriteria yang telah ditentukan. Validasi yang digunakan merupakan validasi e-Modul hasil pengembangan dengan menggunakan angket yang diberikan kepada validator yang terdiri dari ahli materi oleh guru mata pelajaran ekonomi bisnis, ahli media dan ahli bahasa oleh dosen prodi pendidikan ekonomi yang sesuai pada bidangnya.

Instrumen pengumpulan data dalam penelitian dan pengembangan adalah lembar validasi e-Modul dan perangkat pembelajaran berupa lembar validasi RPP dan e-Modul. Lembar validasi tersebut diberikan kepada validator beserta RPP dan draft e-Modul yang akan divalidasi.

Instrumen yang dipakai berupa jawaban skor perbandingan dengan memakai skala likert yakni 4, 3, 2, 1 . Skala penilaian bermakna 1 (tidak baik), 2 (kurang baik), 3 (baik), 4 (sangat baik). Setelah diperoleh skor dari lembar validasi para validator akan dihitung persentase kriteria kuantitatif sehingga mempermudah membaca hasil yang diperoleh.

Tabel 1 Skala Presentase

\begin{tabular}{cc}
\hline $\begin{array}{c}\text { Presentase } \\
\text { Ketuntasan }\end{array}$ & $\begin{array}{c}\text { Taraf } \\
\text { Keberhasilan }\end{array}$ \\
\hline $90-100$ & Sangat Baik \\
$80-89$ & Baik \\
$70-79$ & Cukup \\
$60-69$ & Kurang \\
$\leq 59$ & Sangat Kurang \\
\hline
\end{tabular}


Jurnal PINUS: Jurnal Penelitian Inovasi Pembelajaran, 7 (1), 2021, Kusnul Khotimah, Elis Irmayanti, Bayu Surindra

Sumber: (Arikunto, 2008)

Hasil validasi dari produk yang dikembangkan dari peneliti dapat dikatakan layak untuk diterapkan dalam pembelajaran apabila memperoleh kriteria penilaian skor baik ( $\geq 76 \%)$.

Tindakan pengembangan atau tingkat kelayakan e-Modul melalui uji coba ke lompok kecil dilihat dalam aspek kualitatif sebagai berikut:

Tabel 2 Penentuan Taraf Keberhasilan Tindakan

\begin{tabular}{cc}
\hline $\begin{array}{c}\text { Presentase } \\
\text { Ketuntasan }\end{array}$ & $\begin{array}{c}\text { Taraf } \\
\text { Keberhasilan }\end{array}$ \\
\hline $90-100$ & Sangat Baik \\
$80-89$ & Baik \\
$70-79$ & Cukup \\
$60-69$ & Kurang \\
$\leq 59$ & Sangat Kurang \\
\hline
\end{tabular}

Sumber: (Arikunto, 2008)

HASIL

Desain pengembangan pada penelitian dan pengembangan berpedoman pada model pengembangan ADDIE. Sesuai dengan namanya, model ini terdiri dari lima tahapan, yaitu: (A)nalysis, (D)esign, (D)evelopment, (I)mplementation, (E)valuation. Alasan pemilihan model pengembangan tersebut adalah model pengembangan ADDIE lebih ringkas dibandingkan dengan model pengembangan yang lainnya. Berikut model awal perangkat dan media pembelajaran e-Modul setelah dikembangkan dari model asli perangkat serta media pembelajaran e-Modul.

Tabel 3 Desain Awal Model

Pengembangan

\begin{tabular}{ll}
\hline Desain Asli & $\begin{array}{l}\text { Desain Awal } \\
\text { Pengembangan }\end{array}$ \\
\hline & RPP
\end{tabular}

1. Tujuan pembelajaran belum sesuai dengan KD.

2. Alat dan sumber belajar belum dicantumkan apa saja yang digunakan.

3. Kegiatan pembelajaran daring belum membuat siswa dapat belajar mandiri dan cenderung monoton.

4. Evaluasi atau penilaian terbatas pada penilaian pengetahuan dan penilaian keterampilan.

$$
\text { Bahan Ajar }
$$

1. Bahan ajar yang digunakan masih berupa buku 1. Tujuan pembelajaran disesuaikan dengan KD.

2. Alat dan sumber belajar yang digunakan dicantumkan.

3. Kegiatan pembelajaran daring disusun agar siswa dapat belajar mandiri.

4. Evaluasi atau penilaian ditambah disesuaikan dengan kebutuhan. cetak dan materi pelajaran yang dikirimkan berupa file .doc maupun .pdf

2. e-Modul belum
1. Bahan ajar berbasis teknologi 
Jurnal PINUS: Jurnal Penelitian Inovasi Pembelajaran, 7 (1), 2021, Kusnul Khotimah, Elis Irmayanti, Bayu Surindra

\begin{tabular}{ll}
\hline tersusun. & disusun sesuai \\
pedoman \\
pengembangan \\
e-Modul oleh \\
Direktorat \\
Pembinaan \\
SMA \\
3. e-Modul dapat \\
diakses oleh \\
seluruh siswa. \\
4. e-Modul \\
memuat materi \\
yang \\
disesuaikan \\
dengan kondisi \\
lingkungan \\
siswa dengan \\
memberikan \\
contoh \\
kongkrit. \\
\end{tabular}

Setelah desain awal RPP dan eModul yang dikembangkan secara bersamaan maka tahap selanjutnya adalah uji coba melalui uji validasi. Uji validasi ahli dan praktisi terdiri dari tiga orang validator, yaitu validator ahli materi, validator ahli media, dan validator ahli bahasa yang memiliki kemampuan dan pengalaman pada bidang tersebut.

Tabel 4 Validator Ahli

\begin{tabular}{lll}
\hline No & Validator & Nama \\
\hline 1 & Ahli & Guru mata \\
& Materi & pelajaran ekonomi \\
2 & Ahli & Dosen ahli media \\
& Media & \\
3 & Ahli & Dosen ahli bahasa \\
\hline
\end{tabular}

Bahasa

Hasil validasi ahli dilakukan sebanyak dua kali memperoleh hasil sebagai berikut:

Tabel 5 Hasil Uji Validasi Ahli

\begin{tabular}{llll}
\hline No & Validator & Tahap I & Tahap II \\
\hline 1 & Materi & $80,83 \%$ & $90,83 \%$ \\
2 & Media & $75 \%$ & $93,75 \%$ \\
3 & Bahasa & $65,63 \%$ & $87,5 \%$ \\
\hline
\end{tabular}

Uji validasi ahli dan praktisi pada desain awal model pengembangan dilakukan sebanyak dua kali. Uji validasi ahli sangat diperlukan untuk menguatkan produk yang dikembangkan mencapai tingkat kevalidan dan dinyatakan layak untuk dipakai.

Uji coba terbatas dilakukan melalui validasi perangkat dan media pembelajaran oleh tiga validator ahli sesuai pada bidangnya. Uji coba terbatas dilaksanakan dengan memvalidasi RPP dan media pembelajaran e-Modul yang disesuaikan dengan pedoman pengembangan e-Modul. Uji coba terbatas bertujuan untuk memperoleh keputusan media pembelajaran e-Modul yang dikembangkan layak dan dapat diimplementasikan dalam kegiatan pembelajaran. Uji coba terbatas dilakukan dengan dua tahapan hingga diperoleh draft media pembelajaran yang siap diuji cobakan lapangan secara luas. 
Jurnal PINUS: Jurnal Penelitian Inovasi Pembelajaran, 7 (1), 2021, Kusnul Khotimah, Elis Irmayanti, Bayu Surindra

\section{PEMBAHASAN}

Pada tahap pengembangan perangkat dan e-Modul divalidasi oleh tiga validator ahli yang terdiri dari dua dosen Universitas Nusantara PGRI Kediri dan Guru Mata Pelajaran Ekonomi Bisnis. Aspek validasi yang dinilai pada materi lebih banyak dibanding aspek validasi lainya. Dimana dalam validasi materi terdiri dari beberapa aspek seperti kelengkapan RPP dan isi e-Modul.

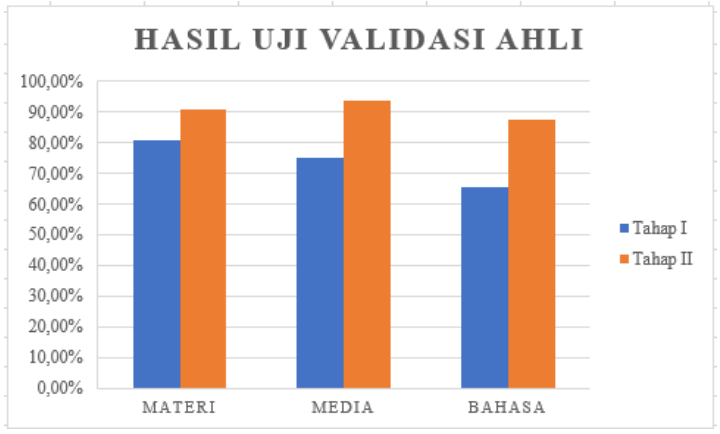

Gambar 2. Hasil Validasi Ahli

Berdasarkan penilaian validator ahli materi, diketahui tahap pertama mendapatkan skor $80,83 \%$ dengan kriteria baik. Meskipun nilai yang didapatkan masuk dalam kriteria baik, sesuai dengan desain penelitian maka tetap dilakukan dua kali uji validasi ahli. Uji validasi ahli kedua didapatkan skor yang lebih tinggi dari tahap pertama yaitu sebesar 90,83\%. Hal tersebut berdasarkan penentuan taraf keberhasilan tindakan dikategorikan sangat baik dan dapat diimplementasikan.

Pada validasi ahli media pada tahap pertama mendapatkan skor $75 \%$ dengan kriteria cukup. Uji validasi ahli kedua didapatkan skor yang lebih tinggi dari tahap pertama yaitu sebesar $93,75 \%$.

\begin{abstract}
Hal tersebut berdasarkan penentuan taraf keberhasilan tindakan dikategorikan sangat baik dan dapat diimplementasikan.

Selanjutnya validasi ahli bahasa pada tahap pertama mendapatkan skor $65,63 \%$ dengan kriteria kurang. Dari perolehan yang kurang tersebut,sesuai dengan desain penelitian maka tetap dilakukan dua kali uji validasi ahli. Uji validasi ahli kedua terjadi peningkatan skor penilaian dari tahap pertama yaitu sebesar $87,5 \%$. Hal tersebut berdasarkan penentuan taraf keberhasilan tindakan dikategorikan baik dan dapat diimplementasikan.
\end{abstract}

Dari hasil penelitian yang dilakukan oleh (Zakiyah, Purnomo and Sugiyanti, 2019), diketahui hasil validasinya yaitu dari hasil ahli media, hasil ahli materi serta tanggapan siswa diketahui bahwa memiliki hasil yang sangat baik. Sehingga pengembangan dari e-modul yang diteliti layak untuk dipakai dalam proses pembelajaran.

E-Modul yang sudah disusun serta dibesarkan cocok dengan pedoman pengembangan e-Modul oleh Direktorat Pembinaan SMA. Sehabis dicoba uji validasi kepada validator pakar hingga diperoleh lapisan e-Modul yang siap digunakan. e-Modul yang siap digunakan serta dinyatakan layak oleh validator pakar diucap desain akhir pengembangan e-Modul. Pada sesi desain akhir pengembangan ini ada sebagian poin pembeda pada media pendidikan e-Modul 
Jurnal PINUS: Jurnal Penelitian Inovasi Pembelajaran, 7 (1), 2021, Kusnul Khotimah, Elis Irmayanti, Bayu Surindra

yang disusun dengan pada biasanya. Penjelasannya sebagai berikut:

Tabel 6 Desain Akhir Model

Pengembangan

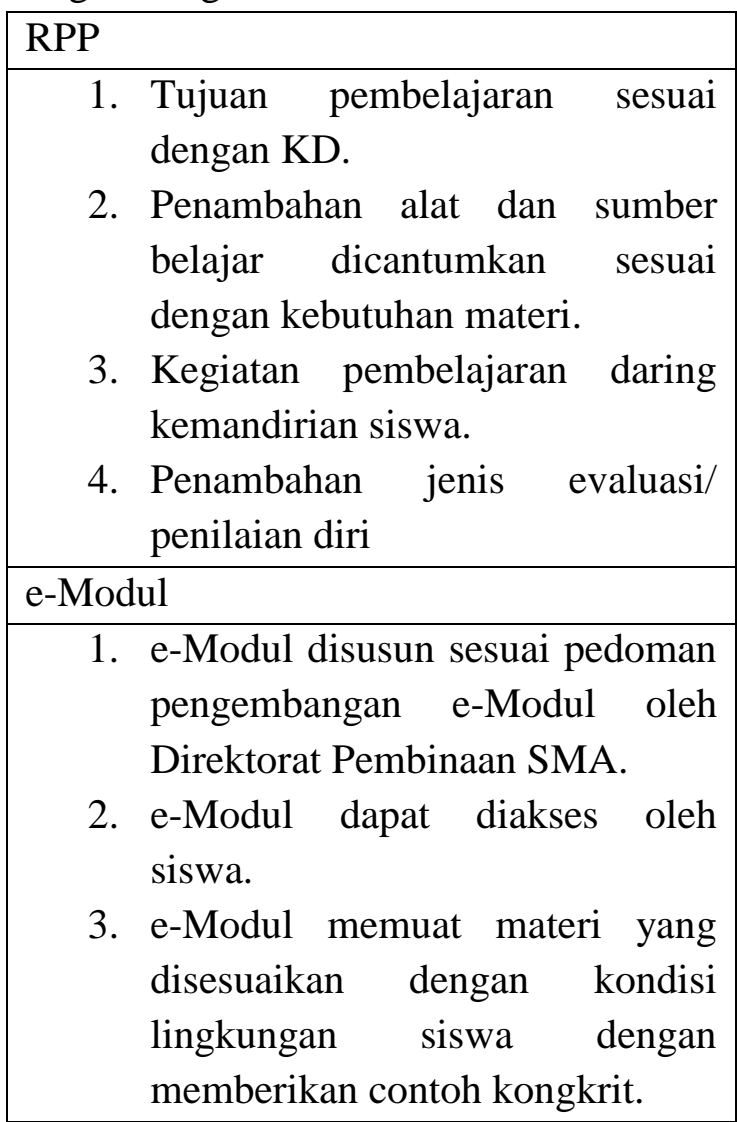

Salah satu faktor yang menjadi kendala/permasalahan dalam penelitian adalah belum terlaksananya tahap implementasi media pembelajaran eModul yang telah disusun. Permasalahan yang mendasari dalam penelitian ini belum bisa diimplementasikan karena keterbatasan waktu peneliti. Pada dasarnya media pembelajaran e-Modul yang dikembangkan telah memiliki indikator layak untuk diimplementasikan. Penelitian dan pengembangan ini sejalan dengan penelitian Diofanu, Wijoyo and Wicaksono (2020), penelitian dilaksanakan dengan model pengembangan ADDIE. Selanjutnya pengembangan modal pembelajaran denan menggunakan model ADDIE ini juga sejalan dengan hasil penelitian (Andiopenta, 2019) diketahui bahwa model pembelajaran layak untuk digunakan karena memiliki hasil yang baik dan efektif, serta mampu memenuhi apa yang dibutuhkan oleh mahasiswa.

Hasil dari proses pengembangan ialah konten video, e-Modul, serta hasil validasi modul, media, serta instrumen dengan rata-rata hasil valid. Hasil dari proses implementasi merupakan berbentuk nilai hasil pre-test serta post test siswa. Hasil dari proses penilaian menampilkan daya guna yang besar serta efisiensi yang besar bersumber pada hasil rata-rata angket reaksi siswa yang bernilai $82,77 \%$.

\section{KESIMPULAN}

Uji validasi oleh ketiga validator ahli, diantaranya ahli materi, ahli media, dan ahli bahasa. Uji validasi dilaksanakan melalui dua tahap. Hasil uji validasi ahli materi pada tahap pertama mendapatkan nilai sebesar 80,83\% dengan kriteria baik dan mengalami peningkatan pada uji validasi tahap kedua dengan nilai 90,83\% dengan kriteria sangat baik. Pada uji validasi ahli media media tahap pertama mendapatkan nilai $75 \%$ dengan kriteria cukup dan pada tahap kedua meningkat dengan nilai $93,75 \%$ dengan kriteria 
Jurnal PINUS: Jurnal Penelitian Inovasi Pembelajaran, 7 (1), 2021, Kusnul Khotimah, Elis Irmayanti, Bayu Surindra

sangat baik. Selanjutnya uji validasi ahli bahasa mendapatkan nilai dengan kriteria cukup yaitu sebesar $65,63 \%$ dan meningkat pada tahap kedua sebesar 87,5\% dengan kriteria baik.

Proses pengembangan e-Modul Ekonomi Mata Pelajaran Ekonomi Bisnis Materi Pelaku Ekonomi dengan model ADDIE yang dilaksakan empat tahapan yaitu tahap analisis, desain, pengembangan, dan evaluasi. Telah diuji validasi oleh tiga validator ahli dan praktisi (materi, media, dan bahasa) serta dinyatakan layak dipakai dalam kegiatan pembelajaran. e-Modul dikembangkan secara efektif untuk dipergunakan selama pembelajaran. Siswa bisa mengakses pada gadget masing-masing, tidak terlalu banyak menghabiskan kuota internet, dan disusun secara sistematis, serta disusun berdasarkan pedoman pegembangan eModul oleh Direktorat Pembinaan SMA.

Media pembelajaran e-Modul yang didesain sedemikian rupa dengan kondisi yang bisa digunakan dalam kegiatan pembelajaran jarak jauh maupun pembelajaran mandiri. Dalam uji validasi pengembangan e-Modul melibatkan guru mata pelajaran ekonomi bisnis dari sekolah terkait yang telah memiliki pengalaman mengajar siswa sebagai validator ahli.

\section{DAFTAR RUJUKAN}

Ali, M. (2007) Ilmu \& Aplikasi Pendidikan. Bandung: PT. IMTIMA.

\author{
Andiopenta (2019) 'Pengembangan \\ Model Pembelajaran \\ Sosiolinguistik Berbasis \\ Lingkungan MelaluiADDIE Model \\ pada PBS-FKIP Universitas \\ Jambi', PINUS, 5(1), pp. 118-127. \\ Available at: \\ https://ojs.unpkediri.ac.id/index.ph \\ p/pinus/article/view/13820/1346.
}

Arikunto, S. (2008) Prosedur Penelitian Suatu Pendekatan Praktik. Jakarta: Rhineka Cipta.

Diofanu, A., Wijoyo, S. H. and Wicaksono, S. A. (2020) 'Pengembangan E-Modul Berbasis Electronic Publication (EPUB) Menggunakan Model Pengembangan ADDIE Pada Mata Pelajaran Pemrograman Dasar di SMK Negeri 4 Malang', Jurnal Pengembangan Teknologi Informasi dan Ilmu Komputer, 4(7), pp. 2204-2211.

Hasbullah (2012) Dasar-dasar Ilmu Pendidikan. Jakarta: Rajawali Pers.

Mudyahardjo, R. (2012) Pengantar Pendidikan. Jakarta: Rajawali Pers.

Pribadi, B. A. (2011) Model Desain Sistem Pembelajaran. Jakarta: Dian Rakyat.

Sugiyono (2017) Metode Penelitian Pendidikan (Pendekatan Kuantitatif, Kualitatif, dan $R \& D)$. Bandung: Alfabeta. 
Jurnal PINUS: Jurnal Penelitian Inovasi Pembelajaran, 7 (1), 2021, Kusnul Khotimah, Elis Irmayanti, Bayu Surindra

Uno, B. H. (2014) Profesi Kependidikan:

Problema, Solusi, dan Reformasi

Pendidikan di Indonesia. Jakarta:

Bumi Aksara.

Zakiyah, H., Purnomo, D. and Sugiyanti, S. (2019) 'Pengembangan E-modul dengan Pendekatan Kontekstual pada Materi Bilangan Bulat SMP Kelas VII', Imajiner: Jurnal Matematika dan Pendidikan Matematika, 1(6), pp. 287-293. doi: 10.26877/imajiner.v1i6.4855. 